\title{
Potensi Jamur Mikoriza Arbuskular Unggul dalam Peningkatan Pertumbuhan dan Kesehatan Bibit Tebu (Saccharum officinarum $\mathbf{L}$.)
}

\author{
Arbuscular Mycorrhizal Fungi Potential in Improving Growth \\ and Health of Sugarcane Seed \\ Citra Mayang Wardhika ${ }^{1}$, Bambang Hadisutrisno ${ }^{2}$, dan Jaka Widada ${ }^{2}$ \\ ${ }^{1}$ Mahasiswa Program Pascasarjana, Program Studi Fitopatologi, Fakultas Pertanian \\ Universitas Gadjah Mada. \\ ${ }^{2}$ Staff Pengajar Program Pascasarjana, Fakultas Pertanian, Universitas Gadjah Mada, Jalan Flora, \\ Bulaksumur, Yogyakarta 55281 Indonesia
}

\begin{abstract}
Sugar cane is one of the important commodities to the national economy and plays a major role in promoting regional development and agro-industries. Indonesia has projected to increase self-sufficiency in sugar cane production, so it must be done. Mycorrhizae which is a form of a mutualistic symbiotic relationship between fungi and plant roots have a high level of ability to improve absorption of nutrients and water that is not available to plants, as well as serve to enhance the resilience of crops against drought, Arbuscular Mycorrhizal Fungi (AMF) can accelerate growth rate, improve the quality and seed power life and can be utilized to increase productivity growth critical land. The research was conducted with observation and identification of AMF types is the most dominant on all isolates were obtained, the multiplication of starter inokulum VAM, and inoculation on the seedling of sugarcane. The results showed that AMF were collected from various locations, retrieved 6 genus VAM, namely: Glomus, Scutellospora, Acaulospora, Gigaspora, Entrophospora, and Sclerocystis. Infectivity test resulted using PS 862 sugarcane clones showed that isolates PKP, MS, KLT, and BTG have the highest infectivity and can be used as a biofertilizer. AMF to sugarcane seedlings reduced the intensity of orange rust disease; main diseases in sugar cane seedlings, it means AMF is potential as biological control.
\end{abstract}

Keywords: VAM, Biofertilizer, Biological Control, Sugarcane

\section{INTISARI}

Tebu merupakan salah satu komoditas perkebunan penting bagi perekonomian nasional dan berperan dalam mendorong pengembangan wilayah dan agroindustri. Indonesia telah mencanangkan untuk swasembada gula, sehingga peningkatan produksi tebu yang merupakan salah satu bahan pokok gula, harus dilakukan. Mikoriza merupakan suatu bentuk hubungan simbiosis mutualistik antara jamur dan perakaran tumbuhan tingkat tinggi. Jamur Mikoriza Arbuskular (JMA) dapat mempercepat laju pertumbuhan, meningkatkan kualitas dan daya hidup bibit tanaman dan meningkatkan pertumbuhan dan produktivitas tanaman lahan kritis. Penelitian ini meliputi identifikasi jenis JMA yang paling dominan pada semua isolat yang diperoleh dari rizosfer tebu, perbanyakan starter inokulum JMA, dan inokulasi pada bibit tebu. Hasil isolasi JMA dari berbagai lokasi, diperoleh 6 genus JMA, yaitu: Glomus, Gigaspora, Acaulospora, Scutellospora, Entrophospora, dan Sclerocystis. Genus Glomus merupakan genus yang dominan dan digunakan dalam pengujian selanjutnya. Hasil uji infektivitas dengan menggunakan klon tebu PS 862 menunjukkan bahwa isolat PKP, MS, KLT, dan BTG yang masing-masing berasal dari Kulon Progo, Sleman, Klaten, dan Batang menunjukkan infektivitas yang paling tinggi dan dapat dijadikan kandidat bahan pupuk hayati. Penambahan JMA pada bibit tebu dapat mengurangi intensitas penyakit karat jingga; penyakit utama pada bibit tebu, yang berarti JMA berpotensi sebagai agens pengendali hayati.

Kata kunci : JMA, Pupuk Hayati, Agen Pengendali Hayati, Tebu 


\section{PENDAHULUAN}

Tebu (Saccharum officinarum L.) adalah satu anggota familia rumput-rumputan (Graminae) yang merupakan tanaman asli tropika basah, namun masih dapat tumbuh baik dan berkembang di daerah subtropika, pada berbagai jenis tanah dari dataran rendah hingga ketinggian $1.400 \mathrm{~m}$ di atas permukaan laut (dpl) (Anonim, 2012).

Tebu merupakan salah satu bahan pokok industri gula. Permasalahan industri gula berpangkal pada empat hal utama yaitu: (1) inefisiensi di tingkat usaha tani; (2) inefisiensi di tingkat pabrik gula; (3) belum efektifnya kebijakan pemerintah guna mendorong perkembangan industri gula Indonesia; dan (4) industri dan perdagangan gula di pasar internasional yang sangat distortif. Masalah klasik pada tingkat usaha tani adalah rendahnya produktivitas dan rendemen. Produktivitas tebu pada perkebunan rakyat yang pangsa produksinya sekitar 68\% hanya sekitar 4-5 ton gula/ha, jauh di bawah produktivitas beberapa negara seperti Australia yang mencapai 97 ton tebu/ha dengan rata-rata rendemen $13,72 \%$ atau setara dengan 13 ton gula/ha. Rendahnya produktivitas tersebut disebabkan oleh ketidaksesuaian lahan, teknik budi daya yang belum optimal, kesulitan kredit atau modal, bias kebijakan pemerintah, dan instabilitas harga (Susila, 2013).

Pemerintah RI mencanangkan pada tahun 2014 dapat swasembada gula, untuk itu diperlukan peningkatan produksi tebu. Mengingat kendala industri gula untuk mendapatkan areal penanaman tebu, karena berebut dengan lahan sawah maka perlu langkah terobosan untuk dapat menanam tebu di lahan-lahan marginal. Untuk keperluan tersebut diperlukan jamur mikoriza untuk meningkatkan pertumbuhan tebu di lahanlahan marginal.

Jamur Mikoriza Vesikula-Arbuskular (JMA) pertama kali dilaporkan oleh Peyronel (1923) dalam Trappe dan Schenk (1982). Hal ini disebabkan karena adanya vesikel dan arbuskular pada akar tanaman yang terinfeksi dan terkolonisasi. Jamur ini menginfeksi tanaman melalui spora, tumbuh dan berkembang dalam jaringan korteks, morfologi jamur ini terdiri dari arbuskula, vesikel, hifa internal dan eksternal.

Tanaman yang bermikoriza cenderung lebih tahan terhadap kekeringan dibandingkan dengan tanaman yang tidak bermikoriza. Setelah periode kekurangan air, akar yang bermikoriza akan cepat kembali normal. Hal ini disebabkan karena hifa jamur mampu menyerap air yang ada pada pori pori tanah saat akar tanaman tidak mampu lagi menyerap air. Penyerapan hifa yang sangat luas di dalam tanah menyebabkan jumlah air yang diambil akan meningkat (Setiadi, 2000).

Peningkatan pertumbuhan tanaman bermikoriza lebih nyata pada tanah dengan tingkat kesuburan rendah atau moderat. Selain meningkatkan $\mathrm{P}$, pengambilan $\mathrm{Zn}, \mathrm{Cu}, \mathrm{S}$ dan unsur-unsur lainnya juga meningkat. Berbagai hasil penelitian menunjukkan bahwa bibit tanaman yang bermikoriza tumbuh lebih cepat, tahan kekeringan, tumbuh lebih baik pada tanah miskin hara dan ber-pH rendah (Sharma dan Johri, 2002).

\section{BAHAN DAN METODE}

Pengambilan sampel tanah dan akar dari perakaran tanaman tebu dilakukan di 8 daerah, yaitu: Tegal, Klaten Utara, Batang, Bantul, Kulon Progo, Sleman, Purworejo, dan PT Perkebunan Nusantara X (Persero), Penelitian Jengkol, Kediri. Penelitian dilakukan di laboratorium Mikologi Pertanian Fakultas Pertanian UGM, di rumah kaca Fakultas Pertanian UGM, dan di rumah kasa di Condong Catur dari bulan April 2012 sampai dengan Februari 2013.

\section{Pengamatan dan identifikasi jenis JMA}

Spora hasil ekstraksi yang diperoleh dari 8 daerah diamati di bawah mikroskop dan diidentifikasi genusnya dengan mengacu pada buku Manual for the Indentification of VA Mychorhizal Fungi (Schenk \& Perez, 1988). Jenis jamur mikoriza yang paling sering dijumpai dicatat sebagai jenis yang dominan.

\section{Perbanyakan starter inokulum JMA}

Masing-masing isolat JMA diinokulasikan pada kecambah jagung berumur 3-4 hari dengan 10 spora JMA setiap kecambah jagung menggunakan medium zeolit. Selama 12 minggu dilakukan penyiraman setiap 2 hari disesuaikan dengan kebutuhan. Pengecekan infeksi mikoriza pada akar dimulai setelah tanaman berumur 8 minggu (Hartini, 2011). Pengamatan dilakukan mengikuti metode Kormanik \& McGraw (1982), dan penghitungan populasi spora mengacu pada metode ekstraksi spora (Daniels \& Skipper, 1982). 


\section{Inokulasi pada bibit tebu}

Masing-masing hasil perbanyakan mikoriza diinokulasikan pada bibit tebu yang berumur 1 bulan sebanyak 20 spora JMA tiap polibag yang berisi $1 \mathrm{~kg}$ tanah. Setelah 1 bulan, bibit tebu dipindah tanam ke polibag yang berisi $10 \mathrm{~kg}$ tanah yang telah diberi pupuk SP-36, $\mathrm{KCl}$, dan batuan fosfat alam. Pemberian dosis pupuk mengacu pada penelitian Purnomo \& Suriadikarta (2008), yaitu 373-436 kg urea/ha, 366-392 kg Kcl/ha, dan SP 36 yang diganti dengan batuan fosfat alam (BFA) sebanyak $816 \mathrm{~kg} / \mathrm{ha}$. Penggunaan dosis pupuk pada penanaman tebu menggunakan pupuk setengah dosis. Pengamatan dilakukan setiap minggu sekali terhadap pertumbuhan bibit dengan mengamati tinggi tanaman dan jumlah daun. Pada akhir pengamatan dilakukan pengamatan berat segar dan berat kering tanaman. Kesehatan tanaman diukur dengan mengamati gejala kelainan yang muncul. Kesehatan lebih difokuskan pada penyakit tanaman tebu, karena yang lebih dominan adalah gangguan penyakit.

\section{HASIL DAN PEMBAHASAN}

\section{Isolasi jamur Mikoriza dan Genus jamur Mikoriza}

Hasil isolasi JMA dari tanah yang diambil dari berbagai lokasi, diperoleh 6 genus JMA, yaitu: Glomus, Gigaspora, Acaulospora, Scutellospora, Entrophospora, dan Sclerocystis (Tabel

Tabel 1. Populasi jenis JMA perakaran tebu dari berbagai lokasi

\section{Populasi JMA di perakaran (spora/g tanah)}

\begin{tabular}{lccccccc} 
Sampel & $\begin{array}{c}\text { Glomus } \\
\text { spp. }\end{array}$ & $\begin{array}{c}\text { Gigaspora } \\
\text { spp. }\end{array}$ & $\begin{array}{c}\text { Acaulospora } \\
\text { spp. }\end{array}$ & $\begin{array}{c}\text { Scutellospora } \\
\text { spp. }\end{array}$ & $\begin{array}{c}\text { Entrophospora } \\
\text { spp. }\end{array}$ & $\begin{array}{c}\text { Sclerocystis } \\
\text { spp. }\end{array}$ & Total \\
\hline BTG & 2,29 & 0,00 & 0,10 & 0,00 & 0,00 & 0,14 & 2,53 \\
MS & 2,59 & 0,03 & 0,06 & 0,09 & 0,00 & 0,01 & 2,78 \\
PWNG & 1,79 & 0,05 & 0,02 & 0,02 & 0,00 & 0,05 & 1,93 \\
SB & 7,70 & 0,07 & 0,05 & 9,95 & 0,04 & 0,01 & 17,82 \\
TGL & 2,66 & 0,07 & 0,04 & 0,10 & 0,00 & 0,02 & 2,89 \\
KLT & 4,51 & 0,02 & 0,01 & 0,02 & 0,00 & 0,85 & 5,41 \\
C4 & 3,27 & 0,00 & 0,00 & 0,00 & 0,02 & 0,05 & 3,34 \\
PKP & 8,37 & 0,00 & 0,00 & 0,02 & 0,00 & 0,02 & 8,41 \\
\hline
\end{tabular}

Keterangan :BTG: Batang; MS: Moyudan, Sleman; PWNG: Ngombol, Purworejo; SB: Sedayu, Bantul; TGL: Tegal; KLT: Klaten; C4: Jengkol, Kediri C4; PKP: Palihan

Dari Tabel 1, dapat diketahui bahwa genusgenus yang sering ditemukan di semua lokasi dan mempunyai populasi paling tinggi adalah genus Glomus, dan genus ini yang digunakan untuk pengujian selanjutnya.

Tahapan identifikasi dilakukan dengan menggunakan Manual for the Identification of VA Mychorrhizal Fungi (Schenk, \& Perez, 1988). Ciri masing-masing spora yang didapatkan, diuraikan sebagai berikut.

1. Glomus spp.

Spora berwarna cokelat kemerahan, bentuk spora agak membulat. Dinding spora terdiri dari 2 lapisan yaitu lapisan A dan lapisan B. Lapisan A merupakan lapisan pertama yang berupa membran tipis. Lapisan B merupakan lapisan yang kedua.
Morfologi mikroskopi Glomus spp. ditunjukkan dalam Gambar 1a.

2. Gigaspora spp.

Tabung kecambah dihasilkan dari dinding spora, mempunyai hiasan spora seperti duri dan mempunyai spora tunggal, spora berbentuk globus, ovoid atau tidak teratur, dan dinding berwarna kekuningan. Morfologi mikroskopinya dapat dilihat dalam Gambar 1b.

3. Acaulospora spp.

Spora berwarna kuning kecoklatan. Proses perkembangan spora ini seolah-olah dari hifa namun sebenarnya tidaklah demikian. Pertamatama ada hifa yang ujungnya membesar seperti spora yang disebut hifa terminus. Morfologi mikroskopinya disajikan dalam Gambar 1c. 

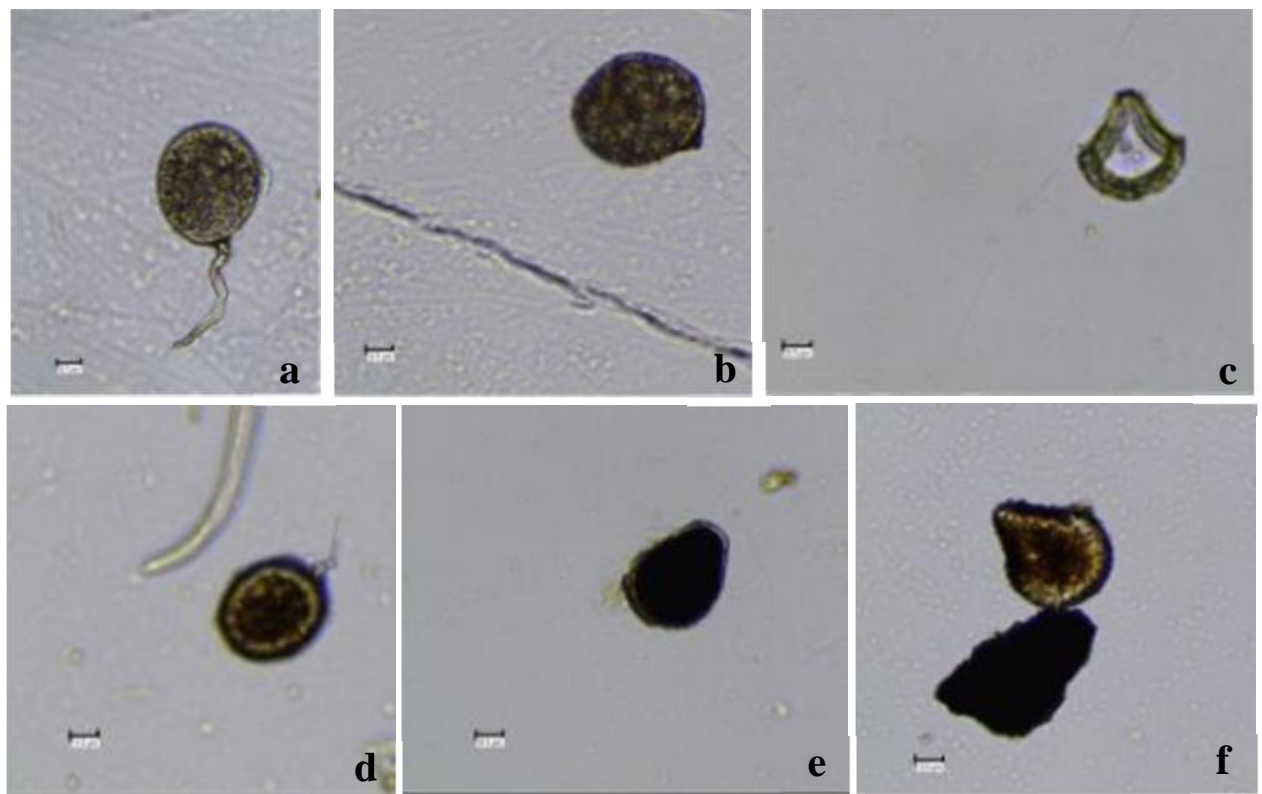

Gambar 1. Spora Mikoriza hasil dari ekstraksi spora dari lokasi pertanaman tebu yaitu: (a) Glomus spp.; (b) Gigaspora spp.; (c) Acaulospora spp.; (d) Scutellospora spp.; (e) Entrophospora spp.; (f) Sclerocystis spp.

4. Scutellospora spp.

Spora berwarna kuning kecoklatan, bentuk agak membulat, dibelakang spora terdapat sel suspensor dengan diameter 5mm. Morfologi mikroskopi Scutellospora spp. ditunjukkan dalam Gambar 1d.

5. Entrophospora spp.

Spora berwarna kuning dan bentuknya agak membulat. Dinding spora secara umum mempunyai 2 lapisan, Lapisan A terdiri dari lapisan tipis dan erletak di bagian dalam berupa membran, dan lapisan B merupakan lapisan kedua. Morfologi mikroskopinya disajikan dalam Gambar 1e.

6. Sclerocystis spp.

Spora tersusun satu persatu, spora berwarna cokelat kemerahan. Dinding spora terdiri atas 1 lapisan yang mengelilingi pusat fleksus. Morfologi mikroskopi Sclerocystis spp. ditunjukkan dalam Gambar 1f.

\section{Kerapatan Spora dan Infeksi Akar Jagung}

Hasil pengamatan populasi spora JMA dan infeksi akar jagung pada medium zeolit dari 8 sampel disajikan dalam Tabel 2.

Hasil perbanyakan inolukum JMA, akan digunakan untuk inokulasi pada tanaman tebu. Masing-masing tanaman tebu akan diinokulasikan sebanyak 20 spora JMA.

\section{Pengujian Infektivitas Inokulum pada Bibit Tebu \\ Inokulum yang diperoleh dari hasil} perbanyakan di medium zeolit diinokulasikan pada bibit tebu yang berumur 1 bulan sebanyak 20 spora per polibag. Pengaruh inokulum hasil teknik perbanyakan terhadap beberapa parameter sifat agronomis bibit tebu yang diamati seperti tinggi tanaman dan jumlah daun disajikan dalam Gambar 2 .

Tabel 2. Populasi spora JMA dan infeksi akar pada jagung

\begin{tabular}{clcc}
\hline No & Lokasi & $\begin{array}{c}\text { Populasi Spora } \\
\text { (spora/g) }\end{array}$ & $\begin{array}{c}\text { Infeksi } \\
\text { Akar } \\
(\boldsymbol{\%})\end{array}$ \\
\hline 1 & TGL & 15,20 & 100,00 \\
2 & MS & 7,20 & 72,00 \\
3 & BTG & 8,80 & 92,00 \\
4 & KLT & 2,80 & 100,00 \\
5 & PWNG & 10,40 & 92,00 \\
6 & SB & 17,00 & 94,00 \\
7 & C4 & 13,20 & 80,00 \\
8 & PKP & 4,00 & 100,00 \\
\hline
\end{tabular}




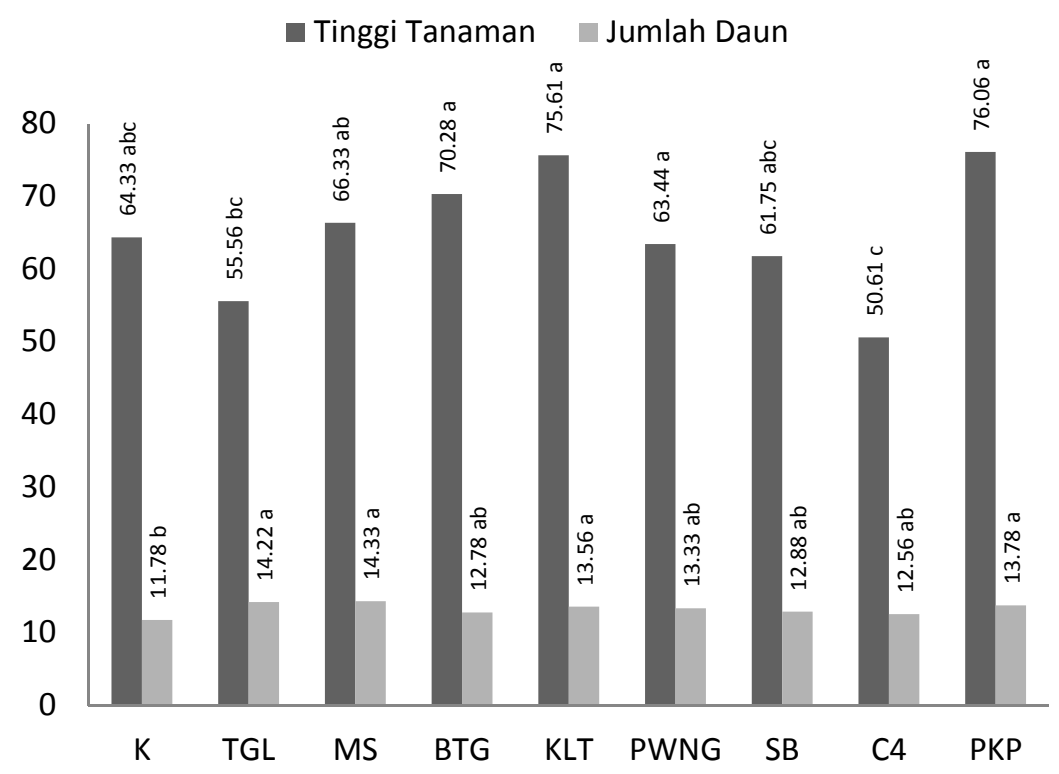

Gambar 2. Pengaruh inokulum terhadap tinggi tanaman dan jumlah daun tebu yang berumur 12 minggu setelah tanam (MST).

Dari Gambar 2 dapat diketahui bahwa isolat PKP, KLT, MS, BTG, menunjukkan pertumbuhan yang didasarkan pada parameter tinggi tanaman dan jumlah daun yang lebih tinggi daripada yang lain.

Meningkatnya tinggi tanaman akibat pemberian mikoriza diduga karena bertambah baiknya kondisi perakaran tanaman. Kondisi perakaran yang lebih baik tentunya menyebabkan unsur hara yang tersedia dalam tanah mudah diserap oleh tanaman dengan bantuan JMA. Menurut Husin (1994; cit Maryeni \& Hervani, 2008) hifa JMA merupakan bagian terpenting dari mikoriza, karena hifa ini akan membantu penyerapan unsur hara dari tanah. Dengan adanya hifa ini, penyerapan hara terutama fosfor menjadi lebih besar dibanding dengan tanaman yang tidak terinfeksi dengan JMA. Fungsi utama dari hifa adalah untuk menyerap fosfor dari dalam tanah.

Kondisi yang cocok untuk perkecambahan dan perkambangan JMA juga sesuai untuk

Pada pengamatan berat segar dan berat kering tebu disajikan di dalam Gambar 3.

Hasil sidik ragam menunjukkan angka yang berbeda nyata pada masing-masing perlakuan dan berbeda nyata dengan kontrol. Sampel MS menunjukkan hasil terbaik berat segar dan berat kering dan diikuti pada sampel PKP, BTG, dan KLT. Hasil berat kering antara MS, PKP, BTG, dan KLT menunjukkan berbeda nyata berdasarkan perkembangan akar stek tebu. Kondisi yang mendorong pertumbuhan akar juga sesuai untuk perkembangan hifa JMA. Pertumbuhan hifa pada tanaman yang lebih baik dipengaruhi oleh kadar $\mathrm{P}$ dalam jaringan tanaman inang, eksudat akar dan $\mathrm{CO} 2$, dan bukan dipengaruhi oleh kadar $\mathrm{P}$ dalam larutan (Jarstfei dan Sylvia, 1993). Selain itu faktor lain yang juga mempengaruhi infeksi JMA antara lain kepekaan inang, faktor iklim, dan faktor tanah. Tanaman dengan ketergantungan fosfat yang tinggi seperti tebu cenderung berasosiasi dengan mikoriza (Setiadi, 1999).

Lozano \& Azcon (2000) menyatakan bahwa JMA dapat meningkatkan ketahanan tanaman pada kondisi kekurangan air melalui peningkatan penyerapan hara, transpirasi daun, dan efisiensi penguunaan air sehingaa terjadi penurunan nisbah akar terhadap tajuk tanaman. Keadaan itu menunjukkan bahwa fotosintesis tanaman meningkat dan fotosintat lebih banyak digunakan untuk pertumbuhan tajuk.

analasis sidik ragam. Hal ini menunjukkan bahwa dengan adanya penambahan JMA pada bibit tebu dapat memperbaiki dan membantu tanaman untuk menyerap air dan unsur hara.

Menurut Smith \& Read (1997) bahwa keberadaan JMA sangat bermanfaat dalam penyerapan air dan unsur hara terutama fosfor. Keadaan yang sama ditunjukkan para parameter berat kering tanaman. pengaruh JMA sangat nyata 
dalam bobot akar tanaman, hal ini sesuai dengan pernyataan Foth (1994; cit Rahmadhani, 2007) bahwa hifa JMA pada bagian luar akan berperan bagi tanaman pada perluasan penetrasi akar.

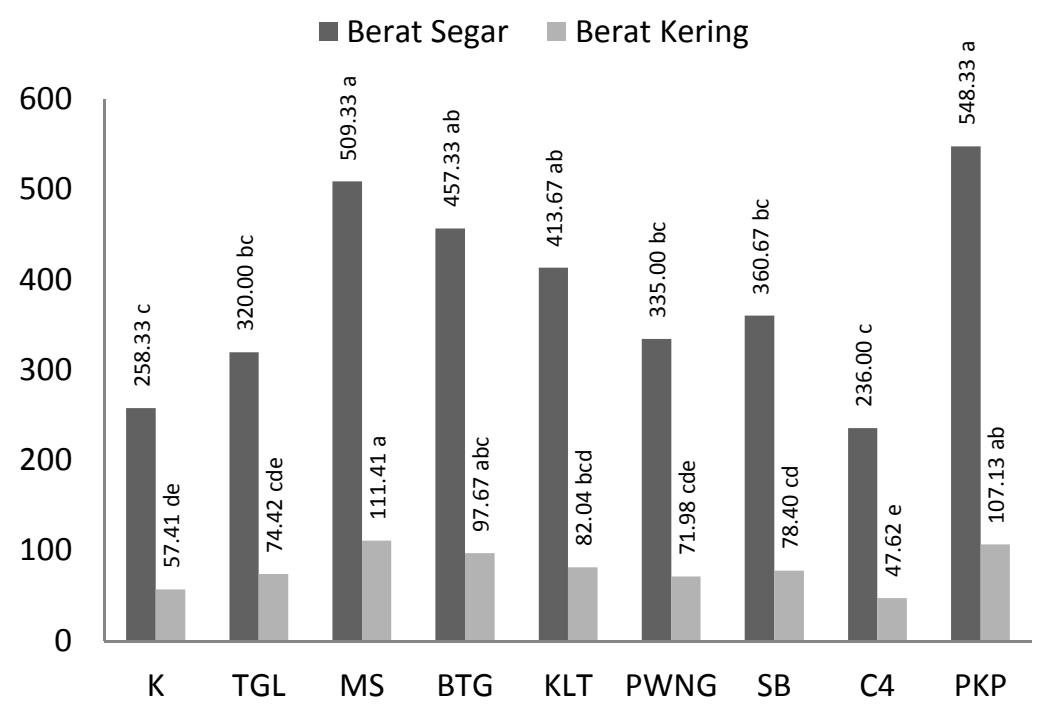

Gambar 3. Pengaruh inokulum terhadap berat segar dan berat kering tebu umur 12 minggu setelah tanam (MST)

Menurut Taufiq (2000) bobot kering tanaman (akar dan tajuk) menunjukkan tingkat efesiensi metabolisme dari tanaman tersebut. Berat kering total hasil panen tanaman merupakan penimbunan hasil bersih asimilasi $\mathrm{CO} 2$ selama pertumbuhan (Gardner et al., 1991). Semakin tinggi bobot kering maka reaksi metabolisme semakin baik karena tanaman memiliki daun yang kokoh sehingga proses fotosintesis berjalan lancar.

Berat kering tanaman memperlihatkan pola tanaman mengakumulasikan produk dari fotosintesis. Pemakaian batuan fosfat pada tanahtanah masam mempunyai prospek untuk meningkatkan hasil dan memperbaiki kesuburan tanah. Penambahan batuan fosfat dapat meningkatkan derajat infeksi oleh JMA dan meningkatkan bobot kering tanaman (Asmah, 1995; cit Rahmadhani; 2007). Aktifitas hifa dalam penyerapan hara terutama $\mathrm{P}$ juga terjadi melalui enzim fosfatase yang dikeluarkan oleh hifa jamur, dengan adanya enzim tersebut ion-ion $\mathrm{P}$ yang terikat kuat pada tanah dapat diuraikan menjadi tersedia di tanah dan dapat diserap oleh tanaman (Hartini, 2011).
Dari hasil pengamatan pada tanaman tebu yang telah diinokulasi JMA, terdapat beberapa penyakit tanaman yang muncul. Hasil pengamatan macam penyakit pada tanaman tebu disajikan di dalam Gambar 4.

Hasil pengamatan inokulasi JMA terhadap pustul karat (Tabel 3) adalah terjadi beda nyata antara kontrol dengan semua perlakuan yang diuji. Jumlah pustul karat tertinggi dijumpai pada kontrol yaitu sebesar 21,85 pustul, dan jumlah pustul terendah adalah pada bibit tebu yang diinokulasi dengan JMA berasal dari Mlese, Klaten (KLT) yaitu 1,74 pustul. Adanya JMA pada bibit tebu dapat menekan atau meminimalkan terjadinya penyakit, karena bibit bermikoriza menjadi lebih sehat, nutrisi, dan hara tercukupi. Intensitas penyakit karat jingga dapat ditekan karena tebu memiliki pertumbuhan yang baik. JMA mampu menyerap unsur hara lebih baik dibandingkan dengan tebu yang tanpa diberi JMA. Terpenuhinya unsur hara dan pertumbuhan yang baik diduga dapat meningkatkan ketahanan tebu terhadap penyakit karat jingga. 

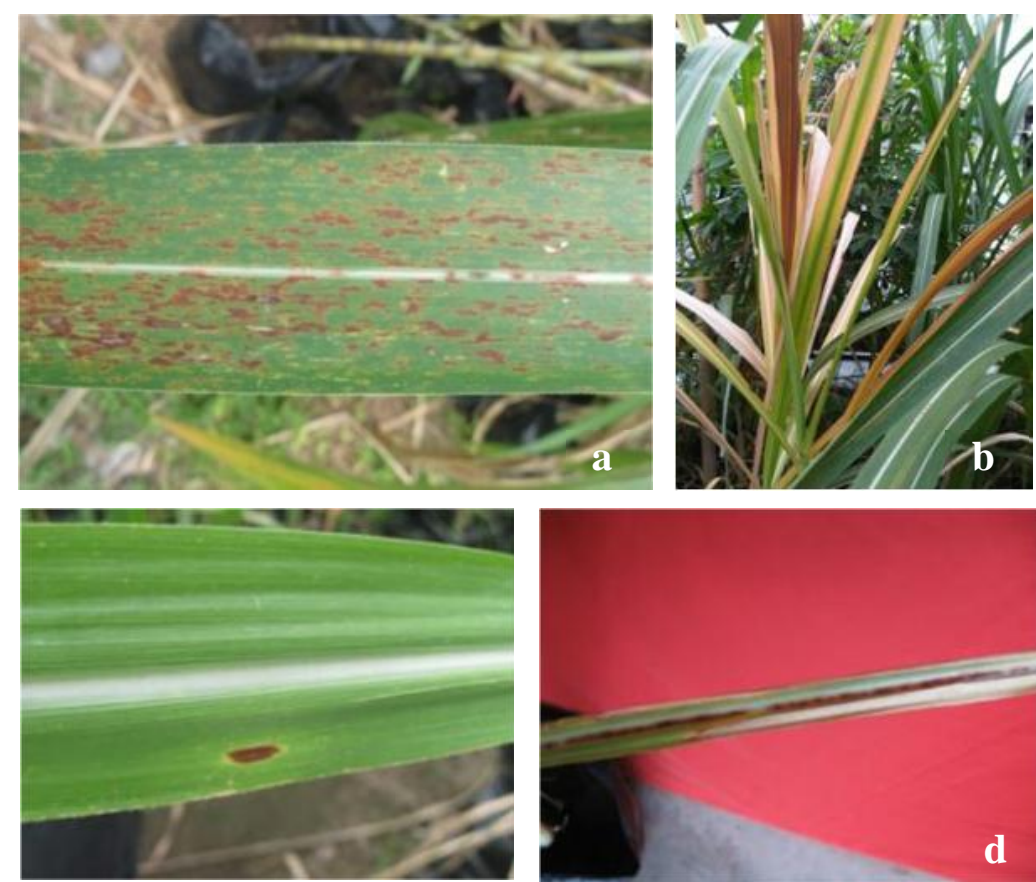

Gambar 4. Penyakit tebu yang ditemukan, yaitu: (a) Karat jingga; (b) Virus garis; (c) Bercak daun; (d) Blendok palsu (bakteri)

Tabel 3. Penyakit karat jingga pada tebu yang diinokulasi JMA

\begin{tabular}{clc}
\hline No & Perlakuan & Jumlah pustul karat \\
\hline 1 & K & $21,85 \mathrm{a}$ \\
2 & BTG & $4,44 \mathrm{~b}$ \\
3 & TGL & $5,55 \mathrm{~b}$ \\
4 & PWNG & $6,92 \mathrm{~b}$ \\
5 & KLT & $1,74 \mathrm{~b}$ \\
6 & MS & $3,62 \mathrm{~b}$ \\
7 & SB & $2,51 \mathrm{~b}$ \\
8 & PKP & $5,74 \mathrm{~b}$ \\
9 & C4 & $7,85 \mathrm{~b}$ \\
\hline
\end{tabular}

Keterangan: angka dalam kolom yang diikuti huruf yang sama tidak berbeda nyata pada uji DMRT taraf $\alpha$ $5 \%$

\section{KESIMPULAN}

1. Hasil eksplorasi pertanaman tebu di berbagai lokasi, diperoleh jamur mikoriza Glomus sp., Gigaspora sp., Acaulospora sp., Entrophospora sp., Sclerocystis sp., dan Sculetolspora sp. Dari keenam genus tersebut, genus Glomus yang dominan.

2. Hasil uji infektivitas dengan menggunakan klon tebu PS 862 menunjukkan bahwa isolat MS, PKP, KLT, dan BTG menunjukkan infektivitas yang paling tinggi dan dapat dijadikan kandidat bahan dalam pupuk hayati.

3. Penambahan Jamur Mikoriza Arbuskular (JMA) pada bibit tebu menyebabkan pertumbuhan bibit tebu menjadi lebih baik yang ditandai dengan nilai berat segar dan berat kering tebu yang lebih tinggi.

4. Penyakit tanaman yang diperoleh dari tebu yang diinokulasi JMA adalah penyakit karat jingga, virus garis, bercak daun, dan blendok palsu (bakteri). 
5. Penyakit karat jingga merupakan penyakit yang paling dominan pada bibit tebu mempunyai intensitas yang lebih rendah pada bibit tebu yang diinokulasi dengan JMA dibandingkan kontrol.

\section{UCAPAN TERIMAKASIH}

Penulis mengucapkan terimakasih kepada berbagai pihak yang telah membantu terutama kepada Balai Besar Perbenihan dan Proteksi Tanaman Perkebunan Surabaya dan PT Perkebunan Nusantara X Penelitian Jengkol, Kediri.

\section{DAFTAR PUSTAKA}

Anonim. 2012. Komoditas Tanaman Tebu. <http://ditjenbun.deptan.go.id/budtansim/ima ges/pdf/tebu.pdf $>$. Diakses pada 22 September 2012.

A.K., Sharma, \& B.N., Johri. 2002. Arbuskular Michorrhizae Interaction in Plants Rhizosphere and Soils. Science Publishers, Inc. United States of America.

Gardner, F.P., P.R., Brent, \& L.M., Roger. 1991. Fisiologi Tanaman Budidaya. Herawati Susilo, penerjemah. Jakarta : Universitas Indonesia Press. Terjemahan dari Physiology of Crop Plants.

Hartini. 2011. Kajian Pemanfaatan Inokulum Jamur Mikoriza Arbuskula untuk Memacu Pertumbuhan dan Kesehatan Bibit Kakao. Tesis.

Jarstfer, W.R. \& D. M. Sylvia, 1993. Inokulum Production and Inoculation Strategies for Vasicular Arbuskular Mycorrhyzae Fungi. P. 349-378. in F.B. Metting Jr. (eds) Soil Mycrobial Ecology. Application in Agriculture and Environmental Management. Marcel Decker Inc. New York-BaselHongkong.

Kuc, J. 2001. Concept and Direction of Indused Systemic Resistence in the Plant and Its Application. European Jurnal of Plant Pathology 107: 7-12.

Kormanik, P.P \& A.C. Mc Graw, 1982. Quantitative ofe Vesikular-Arbuscular Mycorrhizae in Plant Roots. In Schenk, N.C. Methods and Principles of Mycorrhizal Research. The APS. St. Paul, Minnesota.

Lozano, JMR., \& R. Azcon. 2000. Symbiotic Efficiency anf Effectivity of an Autochthonous Arbuscular Mycorrhizal
Glomus sp. from Saline Soils and Glomus Deserticola Under Salinity. Mycorrhiza 10(3) :137-143.

Maryeni, R \& D. Hervani. 2008. Pengaruh Jamur Mikoriza Arbuskula terhadap Pertumbuhan Tanaman Selasih (Ocimum sanctum L.). J. Akta Agrosia 11 (1) : 7-12.

N.C., Schenk, \& Y., Perez. 1988. Manual for the Identification of VA Mycorrhizal Fungi 2nd Edition. By INVAM. University of Florida.

Newsham. K. K., A.H. Fitter, \& A.R. Watterson. 1995. Arbuscular Mycorriza Protect an Annual Grass from Root Pathogen Fungi in Field. Journal of Ecology, 83:991-1000.

Rahmadhani, F. 2007. Pemberian Pupuk Rock Fosfat dan berbagai Jenis Isolat mikoriza Vesikular Arbuskula terhadap Produksi Tanaman Kedelai (Glycine max, L. Merill) pada Tanah Gambut Ajamu, Labuhan Batu. Fakultas Pertanian Universitas Sumatera Utara. Skripsi.

Setiadi, Y. 2000. Pengembangan Cendawan Mikoriza Arbuskula sebagai Alat Biologis untuk Merehabilitasi Lahan Kritis di Indonesia.

Prosiding Seminar Peranan Mikoriza dalam Pertanian yang Berkelanjutan. 28 September 2000, Universitas Padjadjaran Bandung.

Setiadi, Y. 2001. Peranan Mikoriza Arbuskula dalam Rehabilitasi Lahan Kritis di Indonesia. Disampaikan dalam Rangka Seminar Penggunaan Cendawan Mikoriza dalam Sistem Pertanian Organik dan Rehabilitasi Lahan Kritis. Bandung 23 April 2001.

S.E., Smith, \& D.J., Read. 1997. Vesicular Arbuscular Mycorrhizae : growth and Carbon Economy of VA Mycorrhizal Plants. In Mycorrhizal Symbiosis. 2nd ed. New York, Acad, Press

Sieverding, E., 1991. Vesicular-Arbuskular Mycorrhiza Management in Tropical Indegenous Glomales. Deutsche . Jerman.

Talanca, A.H \& A.M.,Adnan. 2005. Mikoriza dan Manfaatnya pada Tanaman. Prosiding Seminar Ilmiah dan Pertemuan Tahunan PEI dan PFI XVI Komda Sul-Sel : 311-315.

Taufiq I.S. 2000. Tingkat Pemberian Fosfor dalam Media Tanaman Campuran Ampas KECAP bagi Pertumbuhan Tanaman Jagung. Skripsi. Bogor.

Trappe, J.M \& N.C. Schenck. 1982. Taxonomy of Fungi Forming Endomycorrhizal. In N.C. Schenck (eds.) Phytopat. Soc. St. Paul. Minnesota. Pp1-9. 